\title{
Glaciochemical investigations of the ice deposit of Vukušić Ice Cave, Velebit Mountain, Croatia
}

\author{
Z. Kern ${ }^{1, *}$, E. Széles ${ }^{2}$, N. Horvatinčić ${ }^{3}$, I. Fórizs ${ }^{1}$, N. Bočić ${ }^{4}$, and B. Nagy ${ }^{5}$ \\ ${ }^{1}$ Institute for Geochemical Research, Hungarian Academy of Sciences, Budapest, Hungary \\ ${ }^{2}$ Institute of Isotopes, Hungarian Academy of Sciences, Budapest, Hungary \\ ${ }^{3}$ Laboratory for Measurements of Low-level Radioactivity, Ruđer Bošković Institute, Zagreb, Croatia \\ ${ }^{4}$ Department of Geography, Faculty of Science, University of Zagreb, Croatia \\ ${ }^{5}$ Department of Physical Geography, Eötvös Loránd University, Budapest, Hungary \\ *now at: Department of Palaeontology, Eötvös Loránd University, Budapest, Pázmány Péter str. 1/c, 1117, Hungary
}

Received: 27 August 2010 - Published in The Cryosphere Discuss.: 2 September 2010

Revised: 26 May 2011 - Accepted: 27 May 2011 - Published: 6 June 2011

\begin{abstract}
The ${ }^{3} \mathrm{H}$ activity and the concentration of 23 metals and metalloids have been analysed in cave ice samples from the perennial cave ice deposit of Vukušić Ice Cave, Velebit Mt., Croatia. The results of tritium measurements exclude a secular age for the upper $2.4 \mathrm{~m}$ of ice deposition, and provide clear arguments that the sampled ice sequence consists of frozen post- 1950 precipitation. Measured concentrations of most of the analysed elements have largely surmounted reported concentrations of similar elements from local precipitation or Alpine snow/firn/ice records, whereas three metals $(\mathrm{Cr}, \mathrm{Cu}, \mathrm{Pb})$ show concentrations comparable to them. Principal component analysis was used to select three groups of elements. The Ca-Mg-governed group (PC1) encompasses the bedrock-related components; their fluctuation might thus reflect the past intensity of dissolution in the epikarst. PC2, with the most characteristic elements being $\mathrm{Na}, \mathrm{Cr}$ and $\mathrm{Pb}$, probably preserved an atmospheric depositional signal. PC3 is governed by $\mathrm{Al}$ and Fe. This probably carries the distal, non-karstic crustal signal and hence might be related to atmospheric circulation (i.e., wind direction and speed).
\end{abstract}

\section{Introduction}

Perennial ice and permafrost occur even in regions where the surface elevation is well below the regional glaciation threshold (snowline), provided that caves provide favourable microclimatic and hydrologic conditions (Mavlyudov, 1989, 2008, Luetscher 2005). As such, cave ice deposits appear as a useful alternative to Alpine glaciers (Schwikowski, 2004) to study the palaeoenvironmental and/or air pollution history. To what extent such underground ice bodies might hold past environmental and climate information, however, is still poorly known. The most intensively studied parameters in cave ice are the stable water isotopes (Yonge and Macdonald, 1999; Fórizs et al., 2004; Perşoiu et al., 2007, 2011, Perşoiu and Pazdur, 2011; Kern et al., 2009, 2011; May et al., 2011), whereas the trace-element composition is almost completely unexplored. Only a few studies reported chemical data of major ions in ice (Citterio et al., 2004a, b; Claussen et al., 2007), while we are unaware of minor and trace elements studies.

In the framework of a bilateral Croatian-Hungarian research project, we have investigated the perennial ice accumulations of the Velebit Mt., Croatia, to evaluate the potential of the glaciochemical signal in the reconstruction of the past local/regional climate and pollution history.

The main objective of this paper is to report the results of a pilot study of major and minor trace element compositions of a cave ice deposit and to compare these data to local precipitation, soil water and other glaciochemical records. In addition, a first-order estimate of the age of the ice body is provided. 


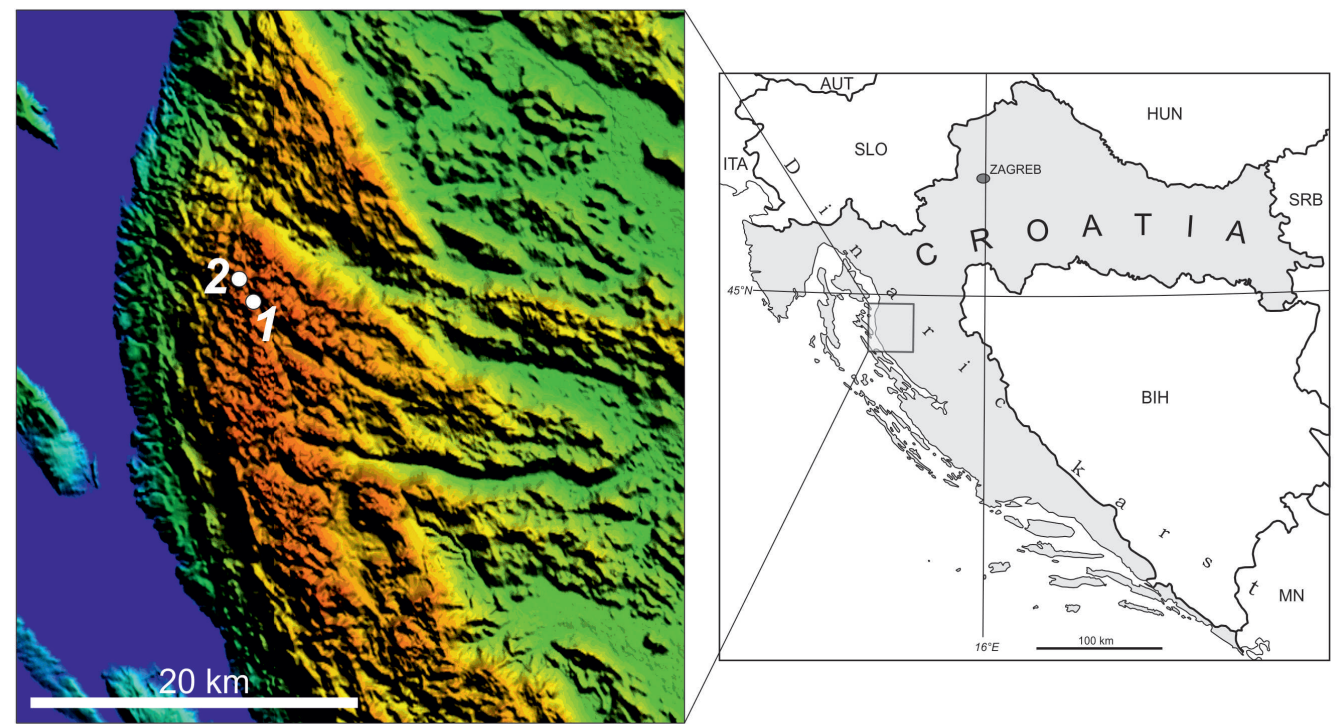

Fig. 1. Location of the Vukušić Ice Cave (1) and the Zavižan meteorological station (2). Gray shading in the map shows the territory of Croatia.

\section{Site description}

\subsection{Description of the cave}

Vukušić Ice Cave (Vukušić snježnica, $44.8^{\circ} \mathrm{N}, 14.98^{\circ} \mathrm{E}$, 1470 m a.s.l.) is located near the Zavižan Peak in the northern part of the Velebit Mountain, in the Croatian part of the Dinaric karst $8 \mathrm{~km}$ off the coast (Fig. 1). To aid visualization of the area a GoogleEarth link is provided in the Supplement.

Vukušić Ice Cave, hosted in Middle Jurassic limestone, consists of an entrance part and two chambers (Fig. 2b). These chambers are connected with the upper entrance via a shaft. Both cave chambers are filled by permanent ice. The length of the cave is $20 \mathrm{~m}$, and the depth, from the upper entrance to the ice level, is $30 \mathrm{~m}$. The thickness of the ice body is up to $15 \mathrm{~m}$. Rock overburden is $<10 \mathrm{~m}$, so any major karstic reservoir can be excluded to contribute karst water to support cave ice formation. Nevertheless, infiltrating water gets in contact with the limestone even if only for a short distance. Direct atmospheric precipitation can be expected to be a significant water source for the formation of ice in Vukušić Ice Cave due to its shallow position and direct exposition through the entrances (Fig. 2). Additionally, a massive snow-plug forms at the lower entrance during winter and the melt water drains onto the cave ice surface during spring and summer. Further, rain and melt water enter through the upper shaft and/or rapidly infiltrate through the thin and fractured rock cover above the cave.

Vukušić Ice Cave is largely a static cave with congelation ice (Luetscher and Jeannin, 2004) and we did not notice any outward air circulation in summer during our explorations. We cannot completely exclude a dynamic ventilation during certain times of the year, however. In winter, air

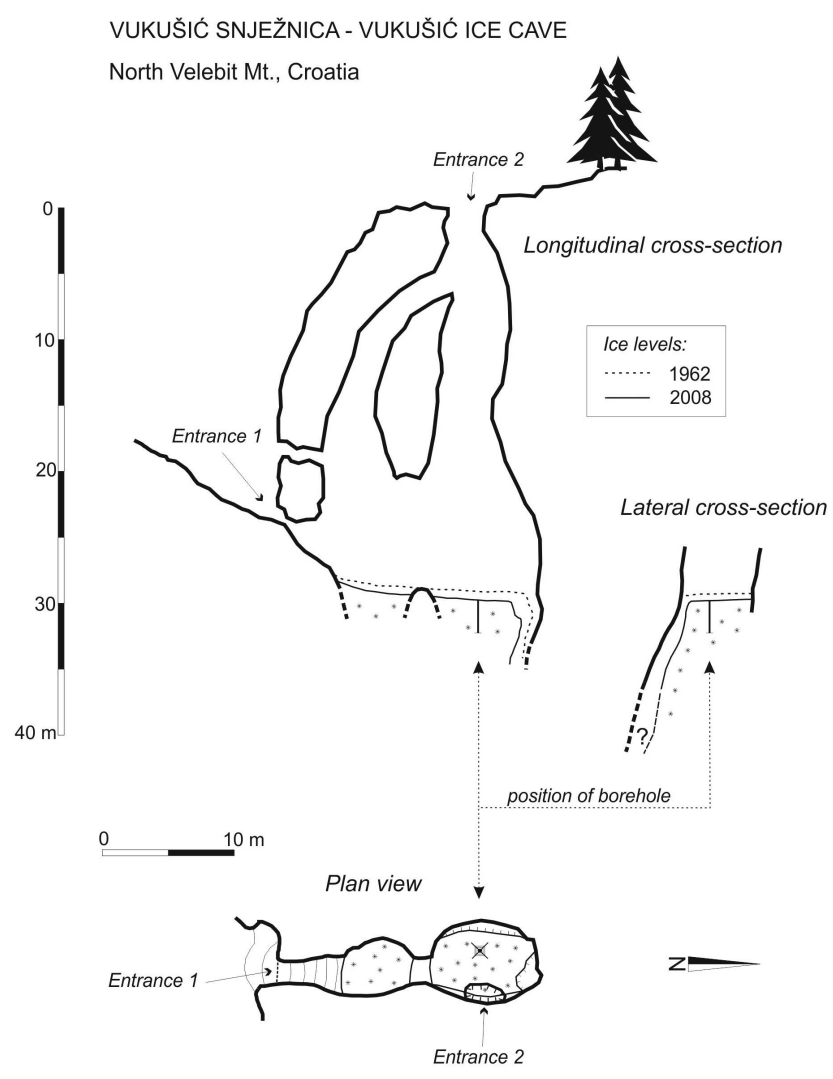

Fig. 2. Sketch of Vukušić Ice Cave (redrawn after Kuhta, 2002) with lines marking the ice level at the given date (according to SDH 1962 and recent observations). The ice core locations are indicated. 
temperature differences apparently trigger air circulation between the cave and outside atmosphere. Further, in summer, similar air temperature differences between different parts of the cave likely give rise to slow convection in the cave.

The first cave survey was made in late summer of 1962 (SDH, 1962). The main chamber was almost completely filled by ice at that time (Fig. 2). Subsequent surveys were carried out in 1996, and by the authors in 2007 and 2008. The ice surface lowered $\sim 20 \mathrm{~cm}$ from 1962 until October 2007 (Kern et al., 2008) and further lowered an additional $6 \mathrm{~cm}$ until October 2008. Local speleologists reported that the elevation of the ice body remained stable until $\sim 2000$. A pronounced loss of ice has been documented since then. The total ice-covered area was only $\sim 50 \mathrm{~m}^{2}$ in October 2007 , and the volume of the ice block was estimated to $550-750 \mathrm{~m}^{3}$. Angular limestone debris cover the surface of the floor ice since our first visit to the cave. This is in contrast to the conditions documented by the first survey when a debris-free ice floor was reported. A detailed survey of the deeper part of the cave is still missing as the gradually expanding side crevasse is still too narrow to descend and explore the abyss.

\subsection{Climatic setting and reference data for the local precipitation}

The local reference data for climate and precipitation chemistry was obtained from the nearby Zavižan meteorological station $\left(44.82^{\circ} \mathrm{N}, 14.98^{\circ} \mathrm{E}, 1594 \mathrm{~m}\right.$ a.s.l.). The distance between Zavižan station and the ice cave is $1500 \mathrm{~m}$. Air temperature at this station follows a typical annual cycle (Fig. 3) and the coldest months are January and February, when the mean monthly temperature is $-4^{\circ} \mathrm{C}$. The warmest months are July $\left(12.4^{\circ} \mathrm{C}\right)$ and August $\left(12.6^{\circ} \mathrm{C}\right)$. The long-term (1958-2009) mean annual precipitation total is fairly high $(1950 \mathrm{~mm})$ and shows two maxima, a minor one in April and a major one in November. Easterly and westerly wind directions dominate (37.4\% and $21.7 \%$, respectively, of the total distribution of wind directions). Easterly wind (bora) is always dry. Humid air and precipitation are brought into the study area by advective westerlies.

The tritium activity had been monitored in precipitation at Zavižan station between September 2000 and December 2003 (Horvatinčić et al., 2005, Vreča et al., 2006). Past tritium activity at Zagreb and Vienna was also used as a regional reference (IAEA, 2004) in order to evaluate the tritium concentration values derived from the cave ice. Decayed tritium activity was calculated using the half-life of $12.32 \mathrm{yr}$ (Lucas and Unterweger, 2000) to allow a comparison with the cave ice data.

The chemical composition of precipitation has been monitoring at Zavižan since 1981 (EMEP, 2010, Špoler Çanić et al., 2009). $\mathrm{Na}, \mathrm{Mg}, \mathrm{K}$ and $\mathrm{Ca}$ were measured both in the local precipitation and in the cave ice. Unfortunately, trace metals are not avaiable from Zavižan. The nearest station where these metals were measured is Iskrba $\left(45.34^{\circ} \mathrm{N}\right.$,

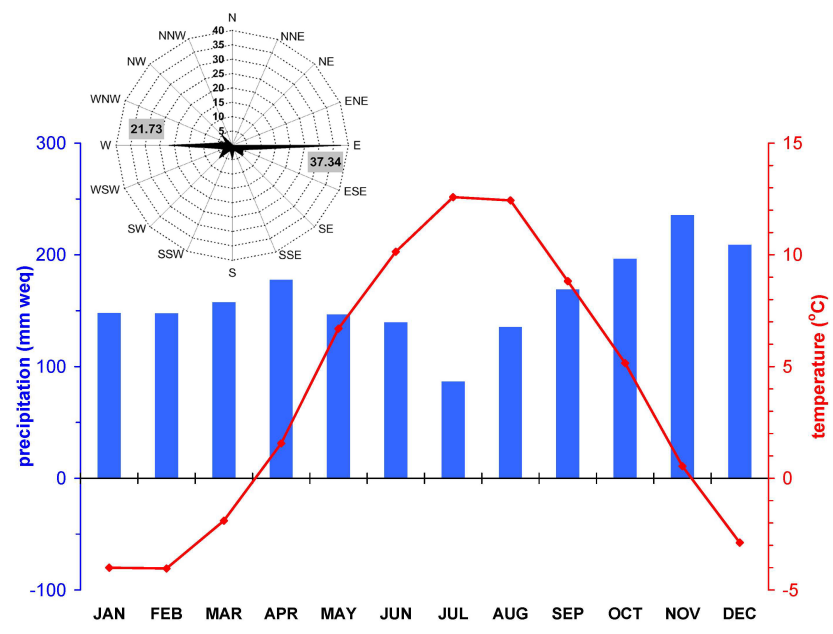

Fig. 3. Climate variables at Zavižan. Monthly mean temperature (red) and precipitation totals (blue, in water equivalents) for the 1958-2009 period. Inset figure: long-term average distribution of wind directions. Percentage values for the prevailing easterly and westerly wind directions are indicated.

$14.52^{\circ}$ E, $520 \mathrm{~m}$ a.s.l.) in Slovenia. There, mean annual concentration data are available for $\mathrm{As}, \mathrm{Zn}, \mathrm{Cu}, \mathrm{Cr}$ and $\mathrm{Pb}$ from 2008 (EMEP, 2010).

The concentration of $\mathrm{Na}, \mathrm{Mg}, \mathrm{K}$ and $\mathrm{Ca}$ was measured in the soil water at $10 \mathrm{~cm}$ depth at a couple of sites in North Velebit (Vrbek, 2005) and were compared with the cave ice data.

Three additional Alpine datasets were used for comparison. Trace elements were determined from an extensive snow sample dataset collected during the 1997-1998 winter season at 21 sites in the Dolomites ca. $300 \mathrm{~km} \mathrm{NW}$ of our study site (Barbante et al., 1999; Gabrielli et al., 2008). The elevation of the sites ranges from 1000 to $3000 \mathrm{~m}$ with an average altitude of $1800 \mathrm{~m}$ a.s.l., so these data are comparable to the elevation of the studied ice cave. Glaciochemical data for major and minor chemical elements were published from snowpit and firn core samples extracted at $3830 \mathrm{~m}$ a.s.l. at Mt. Ortles representing 2009-2006 deposition (Gabrielli et al., 2010; Gabrieli et al., 2011). Mt. Ortles is ca. $400 \mathrm{~km}$ WNW of our cave site. Finally, trace elements data of the 1950-1980 period (Gabrieli, 2008) from the Colle Gnifetti firn/ice core, Monte Rosa (Barbante et al., 2004) were also included. The 1950-1990 time window was used, as it encompasses the most polluted section of the record. The elevation of the sampling site at Colle Gnifetti is at $3830 \mathrm{~m}$ a.s.l., and the distance to Velebit is $570 \mathrm{~km}$. 


\section{Materials and methods}

\subsection{Sample acquisition and handling}

\subsubsection{Ice drilling}

Two drill cores (diameter $3 \mathrm{~cm}$, length $2.4 \mathrm{~m}$ and $26 \mathrm{~cm}$ ) were extracted from the ice deposit on 28 October 2008. The drilling sites were positioned on the flat surface of the ice block (Fig. 2). All depth data are referred to as depth below the 28 October 2008 ice surface.

The deepest $40 \mathrm{~cm}$-long section of the $2.4 \mathrm{~m}$-long core and the $26 \mathrm{~cm}$-long ice core were kept as one sample and labelled as VS_lower and VS_upper, respectively. Both samples were broken and put into 11 plastic bottles.

The upper $2 \mathrm{~m}$-long segment of the $2.4 \mathrm{~m}$-long ice core was cut into 36 segments. The mean sample length is $\sim 5.3 \mathrm{~cm}$ (range 5.0 to $5.7 \mathrm{~cm}$ ). Subsamples were labelled VS1.1 to VS4.6 and VS6.1 to VS7.6 starting from the surface of the ice body. VS5 is not an ice sample as the fifth run got stuck in a branch and only a few centimetres of wood chips were recovered. This wood was embedded in a muddy ice layer. Limestone fragments up to $2 \mathrm{~mm}$ and dark muddy material rich in organic matter were observed in three consecutive samples VS4.6, VS6.1 and VS6.2, corresponding to the $1.24-1.44 \mathrm{~m}$ depth range. This probably indicates a period when ablation of the ice and influx of soil material into the cave occurred. Consequently, the core was subdivided into three main stratigraphic units. The first unit (0-1.24 m) is characterized by clean ice. The second unit (1.24-1.44 m) is composed of dirty ice (probably due to soil contamination). The third unit beneath $1.44 \mathrm{~m}$ is again characterized by clean ice (for a diagram showing this stratigraphy see the Supplement).

No fluid was used during the drilling process in order to minimize contamination (Boutron and Batifol, 1985). In addition, rinsing of the cores was also avoided; instead, mechanical decontamination was applied (Boutron and Batifol, 1985), whereby the outermost $2 \mathrm{~mm}$ of ice were peeled from each core using plastic knives. Knives and tubes had been pre-cleaned with Millipore ultrapure water in the laboratory, dried and kept clean until sampling. Different knives were used for each sample. Core processing was done using plastic gloves, which were washed with distilled water between each core and dried with clean paper wadding.

Each subsample was put into a clean and dry standard $50 \mathrm{ml}$ centrifuge tube, sealed and stored in insulated boxes.

\subsubsection{Sample treatment in the laboratory}

In the laboratory all samples were left to melt completely. Due to the large detrital content of three samples (VS4.6, VS6.1, VS6.2) all samples were filtering using Whatman syringe filters (pore size $0.45 \mu \mathrm{m}$, filter material: acetate cellulose). $100 \mu \mathrm{l}$ distilled concentrated nitric acid (Merck,
Germany) was added to the filtered samples and the samples were subsequently stored in a fridge.

\subsection{Tritium measurements}

Tritium $\left({ }^{3} \mathrm{H}\right)$ activities of VS_upper and VS_lower samples were analysed at the Laboratory for Measurements of Lowlevel Radioactivity, Ruđer Bošković Institute. Tritium in water samples was measured using a liquid scintillation counter (LSC) Quantulus 1220 by electrolytic enrichment of water samples prior the measurement. The system of electrolytic enrichment consists of 20 cells of $500 \mathrm{ml}$ volume and equipment for primary and secondary distillation. The final volume of water sample after electrolysis was $19 \pm 1 \mathrm{ml}$. The average enrichment factor was $20 \pm 1$. A mixture of $8 \mathrm{ml}$ of enriched water and $12 \mathrm{ml}$ of scintillation cocktail Ultima Gold LLT was used for counting in the LSC. Results are reported in tritium units $\left(1 \mathrm{TU}=0.1183 \mathrm{~Bq}^{-1}\right.$; Curie, 1995). The limit of detection is 0.3 to $0.5 \mathrm{TU}$, depending on the measurement duration.

\subsection{Chemical composition of the cave ice}

The element content of the filtered samples was determined using a ThermoFinnigan Element2 Magnetic Sectorfield ICP-MS at the Institute of Isotopes of the Hungarian Academy of Sciences. Samples were analyzed along with blank samples. Instrument operation parameters were: RF power $1340 \mathrm{~W}$, cooling gas flow rate $15.41 \mathrm{~min}^{-1}$, auxiliary gas flow rate $1.011 \mathrm{~min}^{-1}$, nebulizer gas flow rate $0.965 \mathrm{l} \mathrm{min}^{-1}$, solution uptake rate $100 \mu \mathrm{min}^{-1}$, mass window 5 , samples per peak 200 , search window 60 , integration window 300, integration type $5 \times 5$. The appropriate resolution (m/ $\Delta \mathrm{m}$ : 300 (low), 4000 (medium) and 10000 (high)) was chosen for each element depending on the interferences. The sample was introduced using an ASX-520 Autosampler (Cetac) conical nebulizer $\left(1 \mathrm{ml} \mathrm{min}^{-1}\right.$ sample flow rate) and a Scott-type spray chamber.

Procedural blanks were determined as follows: $40 \mathrm{ml} \mathrm{Mil-}$ lipore water was filtered by the same syringe filter placed into plastic centrifuge tubes and was treated identically to cave ice samples. The procedural blank values were subtracted from the concentration and all samples with a final concentration below the limit of detection (LOD, $0.01 \mathrm{ng} \mathrm{g}^{-1}$ ) were discarded.

Forty-five chemical species were screened and 23 were above the detection limit at least in one out of the 36 analysed samples; however, only 12 elements were detected in each ice sample.

Principal component analysis (PCA; Jolliffe, 2002) was carried out to detect the main modes of common variability among elements. Component loadings (eigenvectors), which display the pattern of association of elements with each component, were employed to detect groupings in the ice core chemistry. PCA, using statistiXL v 1.7 beta, was established 


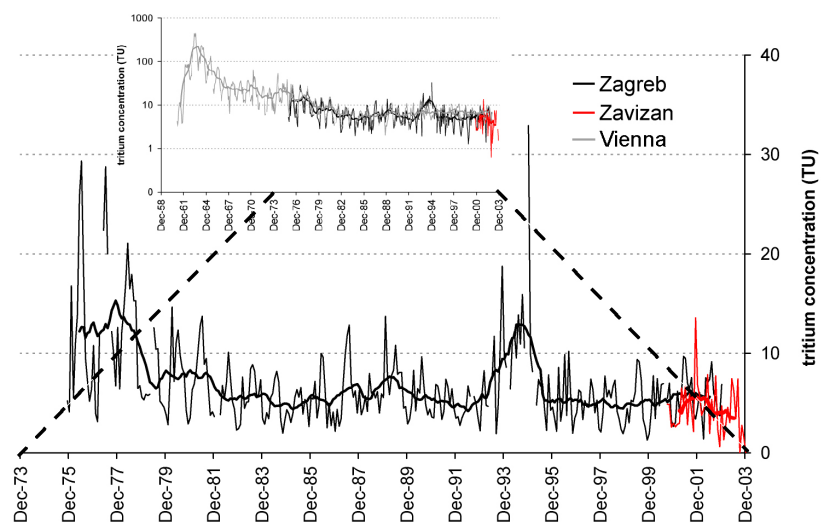

Fig. 4. Decay-corrected tritium activity of past precipitation at Zavižan (red) and Zagreb (black) over the 1973-2003 period. The inset figure shows the same graphs completed with data from Vienna (gray) - the longest regional tritium record. Thin lines show of monthly data, thick lines (12-month moving average) emphasize the annual variability.

on the subset of those 12 elements which were detected in each ice sample. Only PCs with an eigenvalue $>1$ were considered.

\section{Results and discussion}

\subsection{Results of the tritium measurements}

The tritium levels in the VS_lower and VS_upper samples are $1.8 \pm 0.5$ and $9.9 \pm 0.6 \mathrm{TU}$, respectively. The concentration of the upper sample is higher than the measured amount-weighted mean tritium concentration of the local recent (September 2000-August 2003) precipitation (6.75 TU - Horvatinčić et al., 2005). Based on the decay-corrected time series of past ${ }^{3} \mathrm{H}$ concentration of local and regional precipitation (Fig. 4) it is evident that the closest time period when the ice layer of VS_upper sample could deposited is 1991. However, we feel it is unlikely that $\sim 30 \mathrm{~cm}$ of ice were deposited in the early 1990s and are still preserved, if we consider the measured recent ice loss rate of ca. $-6 \mathrm{~cm} \mathrm{yr}^{-1}$ and the long-term (1962-2007) negative rate of ice-level change. Two additional periods whose ${ }^{3} \mathrm{H}$ concentrations in precipitation were similar to those in the VS_upper sample are the early 1970 s until the early 1980 s, as well as a shorter interval between 1954 and 1960. Between these periods (i.e., from 1961 to early 1970s) the decay-corrected activity of the past precipitations is still estimated to be above 10 TU (Fig. 4).

The tritium activity of the lower sample is fairly low but definitely higher than the pre-1953 level, when the natural level of tritium in Central European precipitation was around 5 TU (Roether, 1967), and which have since decayed to $\sim 0.1$ TU level. Much higher atmospheric tritium concentrations, a "by-product" of atmospheric thermonuclear
Table 1. Basic statistics of elemental concentrations measured in the samples of Vukušić ice core. If the concentration of a particular element is below the Limit of Detection (LOD) then LOD/2 was used in calculating the mean concentration. To avoid a bias due to this artificial substitution only those elements are reported for which less than four samples were below LOD. Value given in $\mathrm{ng}^{-1}$.

\begin{tabular}{lrrrr}
\hline & Mean & Median & Min & Max \\
\hline $\mathrm{Na}$ & 375 & 259 & 54 & 1990 \\
$\mathrm{Mg}$ & 174 & 64.1 & 27.8 & 1630 \\
$\mathrm{Al}$ & 70.4 & 50.1 & 9.19 & 231 \\
$\mathrm{~K}$ & 261 & 210 & $<\mathrm{LOD}$ & 1250 \\
$\mathrm{Ca}$ & 7310 & 3660 & 2590 & 47500 \\
$\mathrm{Cr}$ & 0.268 & 0.208 & 0.026 & 1.52 \\
$\mathrm{Mn}$ & 19.5 & 5.75 & 0.755 & 324 \\
$\mathrm{Fe}$ & 31.5 & 26.1 & 3.82 & 88.3 \\
$\mathrm{Co}$ & 0.082 & 0.039 & $<$ LOD & 0.475 \\
$\mathrm{Cu}$ & 0.263 & 0.137 & $<$ LOD & 2.25 \\
$\mathrm{Zn}$ & 42.5 & 32.7 & 5.49 & 148 \\
$\mathrm{As}$ & 0.493 & 0.200 & 0.053 & 3.37 \\
$\mathrm{Rb}$ & 1.08 & 0.284 & 0.071 & 13.42 \\
$\mathrm{Sr}$ & 6.84 & 3.11 & 1.80 & 45.7 \\
$\mathrm{Ce}$ & 0.039 & 0.034 & $<$ LOD & 0.124 \\
$\mathrm{~Pb}$ & 0.241 & 0.204 & 0.056 & 0.563 \\
$\mathrm{U}$ & 0.088 & 0.027 & $<$ LOD & 0.767 \\
\hline
\end{tabular}

weapon tests, appeared in European precipitation around $\sim 1953$ (Eriksson, 1965). So the measured ${ }^{3} \mathrm{H}$ activity of the VS_lower sample suggests mixing of pre-bomb $(<0.1 \mathrm{TU})$ and post-bomb ( $>\sim 10 \mathrm{TU})$ precipitation. As a conservative approximation we suggest that the ice accumulated from the precipitation fallen between 1950 and 1955 .

Assuming a constant depositional rate these ice core samples represent a temporal resolution of $\sim 0.88 \mathrm{yr}$ or $\sim 0.14 \mathrm{yr}$ if the uppermost layer is from the early 1980s or 1960s.

\subsection{Elemental concentrations of the cave ice}

Element concentration data for 36 cave ice samples are presented in the Supplement and mean concentrations of the 17 most abundant elements are shown in Table 1.

$\mathrm{Ca}$ is the most abundant ion in the cave ice. Additional major elements, with median concentrations above $60 \mathrm{ng} \mathrm{g}^{-1}$ and maximum concentrations above $1 \mu \mathrm{gg}^{-1}$ are $\mathrm{Na}, \mathrm{K}$ and $\mathrm{Mg}$. Minor components, with median concentrations ranging from 3 to $50 \mathrm{ng} \mathrm{g}^{-1}$ and maximum concentration between $\sim 40$ and $400 \mathrm{ng} \mathrm{g}^{-1}$ are $\mathrm{Al}, \mathrm{Zn}, \mathrm{Fe} \mathrm{Mn}$ and Sr. Trace components with median concentration below $1 \mathrm{ng} \mathrm{g}^{-1}$ and maximum concentration below $15 \mathrm{ng} \mathrm{g}^{-1}$ are $\mathrm{Cr}, \mathrm{Co}, \mathrm{Cu}, \mathrm{As}, \mathrm{Rb}$, $\mathrm{Ce}, \mathrm{Pb}$ and $\mathrm{U}$.

As expected, the cave ice samples contain much more $\mathrm{Ca}$ and $\mathrm{Mg}$ than the long-term (1981-2009) mean concentration in Zavižan precipitation (Table 2.) This large enrichment of $\mathrm{Ca}$ and $\mathrm{Mg}$ is in agreement with results from other ice 
Table 2. Average elemental concentrations in the three stratigraphic units of the Vukušić ice core and in the local precipitation, soil water, an Italian cave ice and three Alpine snow/firn/ice records. Values are in $\mathrm{ng} \mathrm{g}^{-1}$. Depth ranges of the three stratigraphic units: Mean 1: 0-1.24 $\mathrm{m}$, Mean 2: 1.24-1.44 m, Mean 3: 1.44-2 m.

\begin{tabular}{|c|c|c|c|c|c|c|c|c|c|c|}
\hline & \multicolumn{3}{|c|}{ Vukušić ice core } & \multirow[t]{2}{*}{$\mathrm{Zav}^{\mathrm{a}}$} & \multirow[t]{2}{*}{ Iskrba $^{b}$} & \multirow[t]{2}{*}{$\begin{array}{r}\text { N Velebit } \\
\text { soil }^{c}\end{array}$} & \multirow[t]{2}{*}{$\begin{array}{l}\text { Lo Lc } \\
1650^{d}\end{array}$} & \multirow[t]{2}{*}{$\mathrm{Ort}^{\mathrm{e}}$} & \multirow[t]{2}{*}{$\mathrm{CG}^{\mathrm{f}}$} & \multirow[t]{2}{*}{$\mathrm{Dol}^{\mathrm{g}}$} \\
\hline & Mean1 & Mean2 & Mean3 & & & & & & & \\
\hline $\mathrm{Na}$ & 459 & 415 & 170 & 0.83 & 0.28 & 580 & 44.7 & 44 & & \\
\hline $\mathrm{Mg}$ & 57.4 & 914 & 218 & 0.32 & 0.06 & 460 & 111.5 & 45 & & \\
\hline $\mathrm{Al}$ & 69.2 & 28.3 & 85.9 & & & & & 3.44 & 17.5 & \\
\hline $\mathrm{K}$ & 279 & 532 & 140 & 0.49 & 0.04 & 640 & 19.3 & 19 & & \\
\hline $\mathrm{Ca}$ & 3560 & 33800 & 8000 & 1.56 & 0.31 & 3970 & 589 & 281 & & \\
\hline $\mathrm{Cr}$ & 0.292 & 0.183 & 0.238 & & 0.15 & & & 0.05 & 0.61 & 0.10 \\
\hline Mn & 4.95 & 134 & 18.6 & & & & & 0.83 & 2.4 & \\
\hline $\mathrm{Fe}$ & 28.2 & 44.4 & 35.0 & & & & & 5.34 & 13.7 & 27.3 \\
\hline Co & 0.040 & 0.253 & 0.127 & & & & & 0.01 & 0.03 & \\
\hline $\mathrm{Cu}$ & 0.284 & 0.326 & 0.195 & & 0.68 & & & 0.16 & 0.35 & 0.72 \\
\hline $\mathrm{Zn}$ & 48.8 & 17.3 & 35.6 & & 2.45 & & & 0.96 & 4.20 & 3.5 \\
\hline As & 0.224 & 2.34 & 0.556 & & 0.10 & & & 0.02 & & \\
\hline $\mathrm{Rb}$ & 0.266 & 5.97 & 1.48 & & & & & 0.04 & & \\
\hline $\mathrm{Sr}$ & 2.90 & 33.2 & 8.02 & & & & & 0.68 & & \\
\hline $\mathrm{Ce}$ & 0.034 & 0.049 & 0.049 & & & & & & & \\
\hline $\mathrm{Pb}$ & 0.258 & 0.269 & 0.194 & & 0.80 & & & 0.11 & 4.6 & \\
\hline $\mathrm{U}$ & 0.027 & 0.421 & 0.129 & & & & & 0.00 & 0.02 & \\
\hline
\end{tabular}

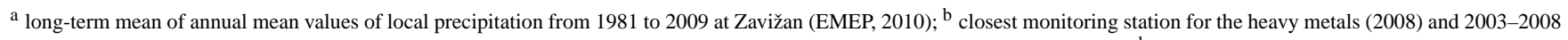
for Na, Mg, K and Ca (EMEP, 2010); ${ }^{c}$ mean annual concentration in soil water at $10 \mathrm{~cm}$ depth, North Velebit (Vrbek, 2005); ${ }^{\mathrm{d}}$ cave ice from LoLc 1650 "Abisso sul Margine dell'Alto Bregai" cave, Lecco, Italy (Citterio et al., 2004a); ${ }^{\mathrm{e}}$ snow samples corresponding to the 2008-2005 deposit collected in a s now pit of Glacier Alto dell'Ortles (Gabrieli et

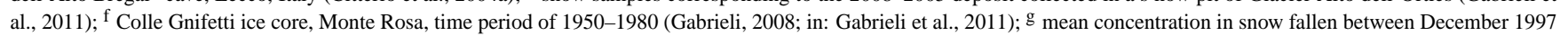
and April 1998 at 21 sites in the Dolomites at altitudes ranging from 1000 to $3000 \mathrm{~m}$ (Gabrielli et al., 2008).

caves (Citterio et al., 2004a; Claussen at al., 2007). The Ca concentrations (minimum, mean, median) are lower than the values reported from Dobšiná Ice Cave (20 ppm; Claussen et al., 2007) but higher than those from an Italian ice cave (ca. 590 ppb; Citterio et al., 2004a).

$\mathrm{Ca}$ and $\mathrm{Mg}$ concentrations in cave ice are much higher than in the local precipitation. Compared to local soil water, we found lower values in the upper stratigraphic unit and higher values in the second stratigraphic unit. In the third stratigraphic unit, both elements show lower concentrations than in the second unit.

The second and third most abundant elements are $\mathrm{Na}$ and $\mathrm{K}$. Their concentrations in the ice also exceed the values reported for local precipitation, but are below the corresponding elemental concentrations in soil water.

The $\mathrm{Ca} / \mathrm{Mg}$ ratio in the cave ice ranges between 29 and 117 , with a median of 55 . The mean ratio in the annual precipitation at Zavižan is 5.9 (range 1.5-12), whereas it is 8.6 in soil water.

Apart from their high concentrations, the large difference in $\mathrm{Ca} / \mathrm{Mg}$ between precipitation and cave ice provides strong evidence that $\mathrm{Ca}$ and $\mathrm{Mg}$ are not sourced from local atmospheric deposition, but are derived from within the karst system. This interpretation is in agreement with Citterio et al. (2004a).
The $\mathrm{Na} / \mathrm{K}$ ratio in cave ice ranges between 0.4 and 4.0 , with a median of 1.7 , whereas it is 1.7 in local precipitation, and 0.9 in the soil water. The $\mathrm{Na} / \mathrm{K}$ ratio in ice shows intermediate values between precipitation and soil water, except for the second stratigraphic unit, where a slightly lower ratio is observed.

These data suggest the dominance of atmospheric deposition in the upper unit. However, an additional source can be suspected as $\mathrm{Na}$ and $\mathrm{K}$ concentrations are much higher in the first unit compared to precipitation. The $\mathrm{Na} / \mathrm{K}$ ratio suggests a soil water dominance in the second unit. This glaciochemical change is in line with the visual stratigraphy of the core, i.e. soil contamination in this unit. However, the 10-fold increase in $\mathrm{Ca}$ concentration and the accompanying decrease in the $\mathrm{Ca} / \mathrm{Mg}$ ratio cannot be explained by an increase in the contribution of soil-derived water. The increased $\mathrm{Na} / \mathrm{K}$ ratio and decreased concentrations in the third unit suggest higher atmospheric deposition and lower soil input; the high $\mathrm{Ca} / \mathrm{Mg}$ ratio, however, again cannot be explained by either precipitation or soil water. To resolve these contradictions, a third source needs to be considered. This component has high $\mathrm{Ca}$ and low $\mathrm{Mg}$ concentrations (to explain the high $\mathrm{Ca} / \mathrm{Mg}$ ratio) but practically no $\mathrm{Na}$ and $\mathrm{K}$. It is likely that limestone is this third component. 


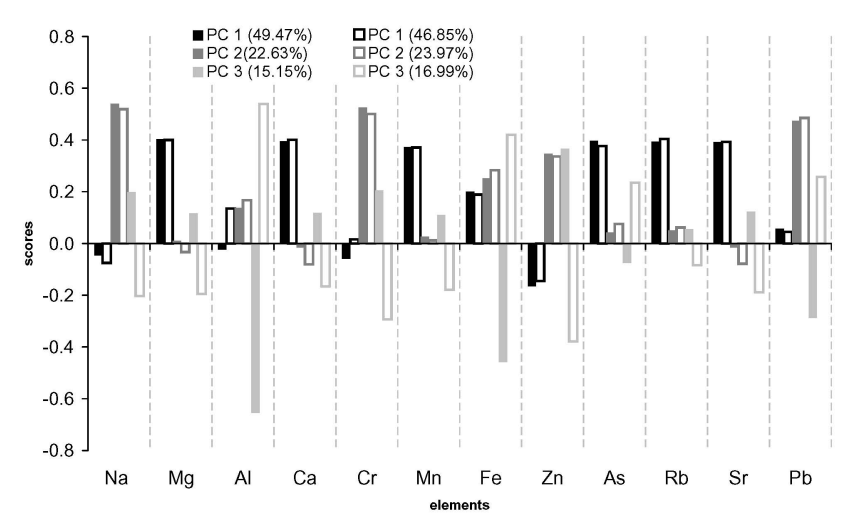

Fig. 5. PCA score coefficients represented as bars with heights proportional to the value of the coefficient. Filled and empty bars represent the scores obtained from PCA established on the full dataset, and on the truncated dataset, respectively (for details see text). Variance distributions of the first three PCs are given in parentheses for both scenarios.

The upper stratigraphic unit $(0-1.24 \mathrm{~m})$ is characterized by values intermediate between precipitation and soil water. The atmospheric fingerprint is significant in the elemental composition of this unit. The second unit $(1.24-1.44 \mathrm{~m})$ is characterized by strongly increased concentrations for most studied elements. $\mathrm{Ca} / \mathrm{Mg}$ and $\mathrm{Na} / \mathrm{K}$ ratios are lower than in the upper unit. Contribution from soil water and dissolution of host rock (limestone) are likely the main sources controlling the chemical composition of this layer. The third unit $(1.44-2 \mathrm{~m})$ is characterized by the lowest $\mathrm{Na}$ and $\mathrm{K}$ concentrations, but elevated $\mathrm{Ca}$ and $\mathrm{Mg}$ concentrations. The $\mathrm{Ca} / \mathrm{Mg}$ ratio remains the same, but the $\mathrm{Na} / \mathrm{K}$ ratio is higher than in the unit above. Limestone dissolution is probably the main source determining the chemical composition of this layer. Moreover, atmospheric deposition probably exceeded the soil water contribution in this unit.

Regarding minor and trace elements, $\mathrm{Zn}$ and As show a significant enrichment (2 to 20 -fold) over Iskrba precipitation. In addition, these two elements, together with $\mathrm{Al}, \mathrm{Mn}$, $\mathrm{Fe}, \mathrm{Rb}$, and $\mathrm{Sr}$, show a significant enrichment ( $>10$-fold) as compared to the Alpine glaciochemical records (Table 2). $\mathrm{Sr}$ is also related to the karstic environment (see Sect. 3.4). Mn and $\mathrm{Rb}$ are remarkably increased in the samples corresponding to the muddy layer (Table 2), most likely due to soil water contribution, thus masking any atmospheric depositional signal.

$\mathrm{Cr}$ was present in the cave ice at similar concentrations as measured in the nearby Slovenian precipitation (EMEP, 2010), while $\mathrm{Cu}$ and $\mathrm{Pb}$ show lower concentrations. The mean concentrations of these elements match the elementspecific range of the Alpine snow/firn/ice records.

\subsection{External and internal chemical signals in the cave ice}

The eigenvalue of the first three principal components exceeds 1 , the chosen threshold, and these explain $87.81 \%$ of the total variance (Fig. 5). PC1 explained half $(44.85 \%)$ of the variance. The score coefficients reveal that the more abundant elements ( $\mathrm{Mg}$ and $\mathrm{Ca}$ ) obtained the highest scores on PC1 (Fig. 5). However, Sr, Co, Rb, Mn show only slightly smaller scores. PC2 carries more than one fifth $(22.63 \%)$ of the total variance. $\mathrm{Na}, \mathrm{Cr}$ and $\mathrm{Pb}$ show the highest score on $\mathrm{PC} 2$. K was not included in the PCA because its concentration was below LOD in the deepest sample, but $\mathrm{K}$ also significantly co-varies with the above three elements. Finally, PC3 explains $16.99 \%$ of the variance and is governed by $\mathrm{Al}$ and $\mathrm{Fe}$.

Since many elements are present at anomalously high concentrations in the samples corresponding to the mud/soil layer it is suspected that this contamination strongly biased the results. To test this hypothesis the PCA analysis was repeated excluding the samples with the unusually high concentrations (VS4.6, VS6.1, VS6.2). Neither the grouping nor the relative magnitudes of the scores changed (Fig. 5) showing that the previous results were robust and unbiased.

The characteristic member of $\mathrm{PC} 1$ group is $\mathrm{Ca}, \mathrm{Mg}$ and $\mathrm{Sr}$ (Fig. 6), typical trace elements of drip water in limestone caves (e.g., Fairchild and Treble, 2009), are strongly correlated with $\mathrm{Ca}$. Hence, these three elements are attributed to limestone dissolution in the karst system. Trace elements such as $\mathrm{Mn}$ and $\mathrm{Rb}$ are strongly correlated with $\mathrm{Ca}, \mathrm{Mg}$ and Sr. The former, however, these are not typical for karst rocks, but are more likely sourced from the soil above.

Elements that do not show a significant positive correlation with the Ca-group are probably indicating a source other than the local bedrock, i.e. the atmosphere.

Among the elements with high concentration, Na obtained the highest score on PC2 (Fig. 5). $\mathrm{Cr}$ and $\mathrm{Pb}$ also have high scores on PC2 and tend to show higher concentrations near the surface of the ice (Fig. 6). $\mathrm{K}$ and $\mathrm{Cu}$ are also positively correlated with the variance of PC2 $(r=0.78, p<0.000$ for both), but they cannot be included into the PCA because K was below LOD in the deepest ice sample and $\mathrm{Cu}$ was below LOD in two samples. This group of elements ( Na, K, $\mathrm{Cr}, \mathrm{Cu}, \mathrm{Pb}$ ) seems a bit unusual, inasmuch as $\mathrm{Na}$ and $\mathrm{K}$ are known to be major components of sea salt, while $\mathrm{Pb}$ and $\mathrm{Cu}$ usually indicate an anthropogenic origin. In addition, as discussed above, $\mathrm{Cr}, \mathrm{Cu}$ and $\mathrm{Pb}$ show concentrations comparable to other regional atmospheric depositional records. We reckon that a joint atmospheric transportation route can explain their common variation. It is well known that $\mathrm{Pb}$ is due by anthropogenic pollution (combustion of leaded gasoline) over the past century (e.g. von Storch et al., 2003) with northern Italy being one of the largest $\mathrm{Pb}$ emission centres of Europe (Pacyna and Pacyna, 2000; von Storch et al., 2003). This has also been documented by glaciochemical evidence 


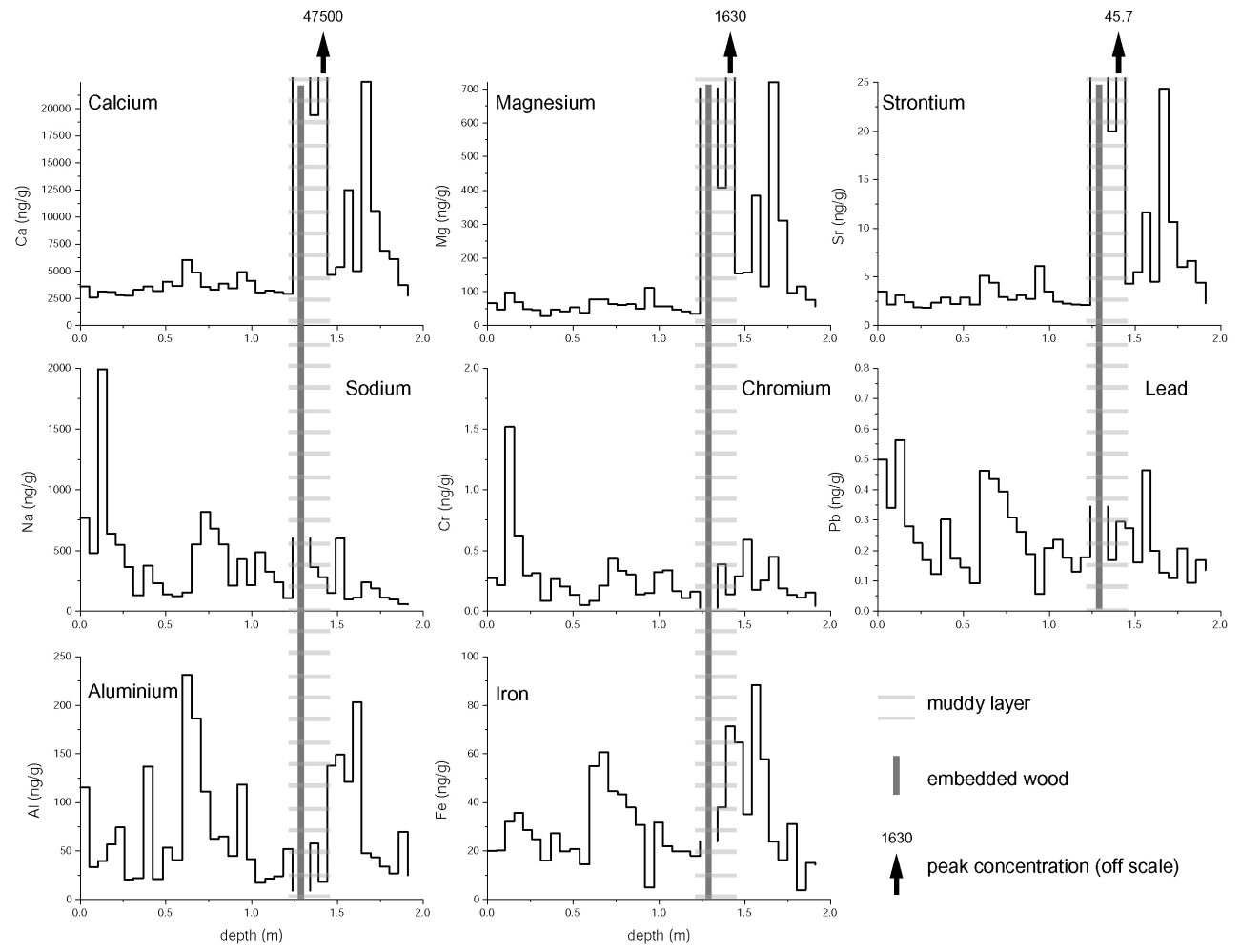

Fig. 6. Concentration profiles of the characteristic elements attributed to the three leading principal components in the Vukušić cave ice core. First row $(\mathrm{Ca}, \mathrm{Mg}, \mathrm{Sr})$ is $\mathrm{PC} 1$, second row $(\mathrm{Na}, \mathrm{Cr}, \mathrm{Pb})$ is $\mathrm{PC} 2$ and the third row $(\mathrm{Al}, \mathrm{Fe})$ is $\mathrm{PC} 3$. The maximum concentrations of the elements in PC1 group located in the deepest sample of the muddy layer are indicated.

(Schwikowski et al., 2004). Westerlies could transport both this $\mathrm{Pb}$ and marine aerosols from the nearby Adriatic Sea to the Northern Velebit.

$\mathrm{Al}$ and Fe show the highest scores on PC3 (Fig. 5). Their mean concentrations in the cave ice exceed the mean concentrations of the 2003-2007 firn at Ortles by $\sim 20$ times for Al, and by 5-8 times for Fe. However, Fe, especially in the upper unit, agrees fairly well with the mean value reported from the Dolomites for the 1997/98 winter (Table 2). Fe and Al may both be due to dust of geogenic and industrial origin. These components probably carry a mixed signal of distal crustal (from outside the karst region) and anthropogenic sources.

$\mathrm{Zn}$ is the only element sharing variance almost equally between two PCs, PC2 and PC3. This might indicate two depositional pathways for the $\mathrm{Zn}$ over the Velebit region. One is linked to the elements grouped in $\mathrm{PC} 2$ and the second one is linked to PC3. The cumulated flux from dual sources could also explain the much higher $\mathrm{Zn}$ concentration compared to other records.

Although no information exists in the Velebit region about past atmospheric deposition rates for the studied metals and metalloids it is worth mentioning that the Croatian national emission inventory (Poljanac et al., 2010) reported increasing emission for $\mathrm{Cu}$ and $\mathrm{Zn}$ over recent decades. The Italian emission inventory also shows a general increase in $\mathrm{Zn}$ emissions (Gabrieli et al., 2011). Consequently, this regional increase in $\mathrm{Zn}$ and $\mathrm{Cu}$ emission may be responsible for the increased $\mathrm{Zn}$ values in the cave ice.

\section{Conclusions}

Two ice cores were extracted from the perennial cave ice deposit of Vukušić Ice Cave, Velebit Mt., Croatia. These ice cores were studied in order to explore the potential of the preserved glaciochemical signal in the reconstruction of past climate and/or pollution history.

The tritium concentration at $2-2.4 \mathrm{~m}$ depth suggests that the ice deposit was built by precipitation which fell $\sim 45 \mathrm{yr}$ ago, and the uppermost $0.26 \mathrm{~m}$-thick ice layer formed between the early 1970s and the early 1980s or between $\sim 1954$ and 1960.

Elemental concentrations and certain elemental ratios indicate a multi-source origin of the ions present in the studied $2 \mathrm{~m}$-long ice core. Atmospheric deposition, soil water and limestone dissolution are regarded as the three major sources of the ions. A qualitative mixing model is proposed by comparing the $\mathrm{Na}, \mathrm{Mg}, \mathrm{K}$ and $\mathrm{Ca}$ concentrations and $\mathrm{Na} / \mathrm{K}$ and $\mathrm{Ca} / \mathrm{Mg}$ ratios from the three stratigraphical units in the ice 
core with the same parameters in local precipitation and soil water.

Due to the karstic setting $\mathrm{Ca}$ is the most abundant ion in cave ice. In a cave-ice environment, only those chemical species possibly preserve reliable atmospheric depositional signals that are not correlated with $\mathrm{Ca}$.

Our results suggest that in the case of Vukušić Ice Cave, $\mathrm{Cr}, \mathrm{Cu}, \mathrm{Pb}$ and $\mathrm{Zn}$ likely reflect past atmospheric deposition. It is also promising that the documented trend of increasing values of $\mathrm{Zn}$ and $\mathrm{Cu}$ in cave ice matches the emission trend reported by local emission inventories.

\section{Supplementary material related to this article is available online at: http://www.the-cryosphere.net/5/485/2011/ tc-5-485-2011-supplement.zip.}

Acknowledgements. Research was funded by the Hungarian National Research Funds (OTKA K67583) and the Ministry of Science, Education and Sport of the Republic of Croatia (Project No. 119-0000000-1299 and Project No. 098-0982709-2741). ZK acknowledges support from TÁMOP 4.2.1./B-09/KMR-20100003. Travel costs were covered by the CRO 04/2006 bilateral cooperation programme. The mass spectrometer facility at the Institute of Geochemical Research was funded by NKTH, project number GVOP-3.2.1.-2004-04-0235/3.0. Constructive comments and suggestions by Dietmar Wagenbach, Michele Citterio and an anonymous reviewer are highly appreciated. We thank Aurel Perşoiu for his kind help in improving the English. We are grateful also to editor Christoph Spötl for his great help in correcting and improving the quality of the manuscript.

Edited by: C. Spötl

\section{References}

Barbante, C., Cozzi, G., Capodaglio, G., van de Velde, K., Ferrari, C., Boutron, C. and Cescon, P.: Trace element determination in alpine snow and ice by double focusing inductively coupled plasma mass spectrometry with microconcentric nebulization, J. Anal. Atomic Spectrom., 14, 1433-1438, 1999.

Barbante, C., Schwikowski, M., Doring, T., Gäggeler, H.W., Schotterer, U., Tobler, L., van de Velde, K., Ferrari, C., Cozzi, G., Turetta, A., Rosman, K., Bolshov, M., Capodaglio, G., Cescon, P., and Boutron, C: Historical record of European emissions of heavy metals to the atmosphere since the 1650s from Alpine snow/ice cores drilled near Monte Rosa, Env. Sci. Tech., 38, 4085-4090, 2004.

Boutron, C. F. and Batifol, F. M.: Assessing laboratory procedures for the decontamination of polar snow or ice samples for the analysis of toxic metals and metalloids, Ann. Glaciol., 7, 7-11, 1985.

Citterio, M., Turri, S., Bini, A., Maggi, V., Pelfini, M., Pini, R., Ravazzi, C., Santillini, M., Stenni, B., and Udisti, R.: Multidisciplinary approach to the study of the LoLc 1650 "Abisso sul margine dell'Alto Bregai” ice cave (Lecco, Italy), Theor. Appl. Karst., 17, 27-44, 2004a.
Citterio, M., Turri, S., Bini, A., and Maggi, V.: Observed trends in the chemical composition, $\delta^{18} \mathrm{O}$ and crystal sizes vs. depth in the first core from the LoLc 1650 "Abisso sul margine dell' Alto Bregai” ice cave (Lecco, Italy), Theor. Appl. Karst., 17, 45-50, 2004b.

Claussen, H. B., Vrana, K., Hansen, S. B., Larsen, L. B., Baker, J., Siggaard-Andersen, M.-L.; Sjolte, J., and Lundholm, S. C.: Continental ice body in Dobšiná Ice Cave (Slovakia) - part II, Results of chemical and isotopic study, in: Proceedings of the 2nd International Workshop on Ice Caves, edited by: Zelinka, J., Liptovsky Mikulás, 29-37, 2007.

Curie, L. A.: Nomenclature in evaluation of analytical methods including detection and quantification capabilities, (IUPAC Recommendation 1995), Pure Appl. Chem., 67, 1699-1723, 1995.

EMEP: available at: http://tarantula.nilu.no/projects/ccc/ sitedescriptions/hr/index.html, last access: 12 July 2010.

Eriksson, E.: An account of the major pulses of tritium and their effects in the atmosphere, Tellus, 17, 118-130, 1965.

Fairchild, I. J. and Treble, P. C.: Trace elements in speleothems as recorders of environmental change, Quat. Sci. Rev., 28, 449-468, doi:10.1016/j.quascirev.2008.11.007, 2009.

Fórizs, I., Kern, Z., Nagy, B., Szántó, Zs., Palcsu, L.m and Molnár, M.: Environmental isotope study on perennial ice in the Focul Viu Ice Cave, Bihor Mts., Romania, Theor. Appl. Karst., 17, 6169, 2004.

Gabrieli, J.: Trace elements and polycyclic aromatic hydrocarbons (PAHs) in snow and ice sampled at Colle Gnifetti, Monte Rosa $(4450 \mathrm{~m})$, during the past 10000 years: environmental and climatic implications, PhD thesis, University Ca' Foscari of Venice, Italy, 2008.

Gabrieli, J., Carturan, L., Gabrielli, P., Turetta, C., Kehrwald, N., Cozzi, G., Staffler, H., Dinale, R., Seppi, R., dalla Fontana, G., Thompson, L., and Barbante, C.: Seasonal impact of natural and anthropogenic emissions on the highest glacier of the Eastern European Alps, Atmos. Chem. Phys. Discuss., 11, 6493-6530, doi:10.5194/acpd-11-6493-2011, 2011.

Gabrielli, P., Cozzi, G., Torcini, S., Cesconi, P., and Barbante, C.: Trace elements in winter snow of the Dolomites (Italy): a statistical study of natural and anthropogenic contributions, Chemosphere, 72, 1504-1509, 2008.

Gabrielli, P., Carturan, L., Gabrieli, J., Dinale, R., Krainer, K., Hausmann, H., Davis, M., Zagarodnov, V., Seppi, R., Barbante, C., Dalla Fontana, G., and Thompson, L. G.: Atmospheric warming threatens the untapped glacial archive of Mt. Ortles, South Tyrol, J. Glaciol., 56, 843-853, 2010.

Horvatinčić, N., Krajcar Bronić, I., Barešić, J., Obelić, B., and Vidič, S.: Tritium and stable isotope distribution in the atmosphere at the coastal region of Croatia. in: Isotopic composition of precipitation in the Mediterranean Basin in relation to air circulation patterns and climate, edited by: Gourcy, L., IAEATECDOC-1453, 37-50, 2005.

IAEA 2004: Isotope Hydrology Information System, The ISOHIS Database, available at: http://isohis.iaea.org (last access: 17 March 2010), 2004.

Jolliffe, I. T.: Principal component analysis, second edition, Springer, New York, 2002.

Kern, Z., Bočić, N., Horvatinčić, N., Fórizs, I., Nagy, B., and László, P.: Palaeoenvironmental records from ice caves of Velebit Mountains - Ledena Pit and Vukušić Ice Cave, Croatia. in: 3rd 
International Workshop on Ice Caves Proceedings, edited by: Kadebskaya, O., Mavlyudov, B. R., and Pyatunin, M., Kungur, 108-113, 2008.

Kern, Z., Fórizs, I., Perşoiu, A., and Nagy, B.: Stable isotope study of water sources and of an ice core from the Borţig Ice Cave, Romania, Data Glac. Stud., (Materialy Glyatsiologicheskikh Issledovaniy), 107, 175-182, 2009.

Kern, Z., Fórizs, I., Pavuza, R., Molnár, M., and Nagy, B.: Isotope hydrological studies of the perennial ice deposit of Saarhalle, Mammuthöhle, Dachstein Mts, Austria, The Cryosphere, 5, 291298, doi:10.5194/tc-5-291-2011, 2011.

Kuhta, M.: Inventarizacija speleoloških objekata na podruèju Nacionalnog parka "Sjeverni Velebit", Inventarisation of the speleological features in the area of the National part "Sjeverni Velebit”, Speleološki klub Željezničar, Speleological club Željezničar, Zagreb, 52 pp., 2002.

Lucas, L. L. and Unterweger, M. P.: Comprehensive review and critical evaluation of the half-life of tritium, J. Res. Natl. Inst. Stand. Technol., 105, 541-549, 2000.

Luetscher, M.: Process in ice caves and their significance for paleoenvironmental reconstructions, PhD thesis, SISKA, Switzerland, 51 pp., 2005.

Luetscher, M. and Jeannin, P.: A process-based classification of alpine ice caves, Theor. Appl. Karst., 17, 5-10, 2004.

May, B., Spötl, C., Wagenbach, D., Dublyansky, Y., and Liebl, J.: First investigations of an ice core from Eisriesenwelt cave (Austria), The Cryosphere, 5, 81-93, doi:10.5194/tc-5-81-2011, 2011.

Mavlyudov, B. R.: Snow and ice formations in caves and their regime, in: Proceeding of the 10th International Congress of Speleology, Budapest, 295-297, 1989.

Mavlyudov, B. R.: Oledenie pescher (Caves glaciation: in Russian) Russian Academy of Sciences, Moscow, Russia, 2008.

Pacyna, J. M. and Pacyna, E. G.: Atmospheric emissions of anthropogenic lead in Europe: Improvements, updates, historical data and projections, GKSS Report no. 2000/31, Geesthacht, Germany, 2000.

Perşoiu, A., Bojar, A.-V., and Onac, B. P.: Stable isotopes in cave ice: what do they tell us?, Stud. Univ. Babeş-Bolyai, Geologia, 52, 59-62, 2007.

Perşoiu, A. and Pazdur, A.: Ice genesis and its long-term mass balance and dynamics in Scărişoara Ice Cave, Romania, The Cryosphere, 5, 45-53, doi:10.5194/tc-5-45-2011, 2011.
Perşoiu, A., Onac, B. P., Wynn, J., Bojar, A.-V., and Holmgren, K.: Stable isotopes behavior during cave ice formation by water freezing in Scărişoara Ice Cave, Romania. J. Geophys. Res., 116, D02111 doi:10.1029/2010JD014477, 2011.

Poljanac, M., Svedek, I., and Kos, R.: Republic of Croatia informative inventory report to LRTAP convention for 2008, Submission to the Convention on Long-range Transboundary Air Pollution, EKONERG Ltd, Zagreb, 172 pp., 2010.

Roether, W.: Estimating the tritium input to groundwater from wine samples: ground-water and direct run-off contribution to central European surface waters, in: Proceedings of IAEA Conference on Isotopes in Hydrology, IAEA, Vienna, 73-90, 1967.

Schwikowski, M.: Reconstruction of European Air Pollution from Alpine Ice Cores, in: Earth Paleoenvironments: Records Preserved in Mid- and Low-Latitude Glaciers, edited by: Cecil, L. D., Green, J. R., and Thompson, L. G., Kluwer Academic Publishers, Dordrecht, 95-119, 2004.

Schwikowski, M., Barbante, C., Doering, T., Gäggeler, H. W., Boutron, C., Schotterer, U., Tobler, L., van de Valde, K., Ferrari, C., Cozzi, G., Rosman, K., and Cescon, P.: Post-17thcentury changes of European lead emissions recorded in highaltitude Alpine snow and ice, Env. Sci. Tech., 38, 957-964, doi:10.1021/es034715o, 2004.

SDH: Speleološki objekti na karti 1:50 000 Senj 1, Speleological features on the map 1:50 000 Senj 1, Speleološko društvo Hrvatske, Croatian speleological society, Zagreb, 18 pp., 1962.

Špoler Çanić, K., Vidič, S., and Klaić, Z. B.: Precipitation chemistry in Croatia during the period 1981-2006, J. Environ. Monit., 11, 839-851, doi:10.1039/b816432k, 2009.

Yonge, C. J. and Macdonald, W. D.: The potential of perennial cave ice in isotope paleoclimatology, Boreas, 28, 357-362, doi:10.1111/j.1502-3885.1999.tb00225.x, 1999.

Von Storch, H., Costa-Cabral, M., Hagner, C., Feser, F., Paczyna, J., Paczyna, E., and Kolb, S.: Four decades of gasoline lead emission and control policies in Europe: a retrospective assessment, Sci. Total Environ., 311, 151-176, 2003.

Vrbek, B.: Kvaliteta padalina i otopine tla nacionalnih parkova "Plitvicka jezera", "Severnij Velebit" i "Risnjak", Rad. Sumar. Inst., 40(1), 19-30, Jastrebarsko, 2005.

Vreča, P., Krajcar Bronić, I., Horvatinčić, N., and Barešic, J.: Isotopic characteristics of precipitation in Slovenia and Croatia: Comparison of continental and maritime stations, J. Hydrol., 330, 457-469, 2006. 